\title{
The KGB (Russian Secret Police): Its composition, aims and methods
}

\author{
Lt Cdr H.G. Graser*
}

\section{Introduction}

Any discussion of the Russian Secret Police, or KGB ('Committee for State Security') must of necessity be preceded by a brief outline of the USSR's true political set-up.

There are two primary governing bodies in the Soviet Union: one is the Supreme Soviet and its Presidium - the other the Communist Party and its Central Committee and Politburo. Put into their proper perspective, this emerges: the Supreme Soviet, which appoints Ministerial staff and runs the USSR's 'government', is in fact no more than a rubber stamping body of men who see to it that the decisions of the Communist Party are duly ratified and implemented.

To ensure that its directives are properly adhered to, and to prevent counter-revolutionary activity against the Party, the KGB controls the USSR security apparatus.

The KGB occupies a central position in the USSR's organigram of executive, legislative and judicial dispensation. More to the point: it is the coercive arm of the Communist Party's Politburo - which happens to combine all three moments of authority inside Russia, and a good deal outside of it in Soviet satellite and client states. The single authority to which the KGB is beholden inside the Politburo and its Central Committee exercises command over it directly. Consequently, KGB officers of relatively low rank can ignore or overrule orders inside the military, militia (normal police) or any other regulative body, given by senior officers or officials. A single attribute counts for everything: unquestioning loyalty and obedience. In return, KGB officers are rewarded lavishly with generous salaries, perks and goods in kind of which the ordinary Russian can only dream.

This does not mean, however, that the KGB itself is not under continuous and relentless scrutiny itself. Members of this fraternity can never be sure who is spying on whom, and how long their sinecure may last: the death of a Soviet supremo may precipitate massive upheavals, and the dismissal of a commander may cause his syco- phants' careers to take a dive. Still, fear and greed make a formidable combination that keep even the grossest of opportunists in line. As a self-contained unit with its own schools, shops, holiday resorts, agricultural production centres and training camps, the KGB has virtually no contact with the people outside of its official function which include surveillance, interrogation, prison administration (although nominally under the Minister of the Interior or the MVD, the Gulag - acronym for prison administration - is under KGB supervision), border control, passport and emigration, political and economic as well as censorship investigations, in addition to the guarding of the Kremlin and its bosses. Contact is strictly discouraged in order to maintain a closed-shop atmosphere among personnel. The KGB has a legal right to demand of anyone that he or she inform on suspected 'anti-Soviet' elements: Soviet statutory law makes it a criminal offence to refuse to do so.

\section{Lenin}

What Lenin said sixty-five years ago, still applies: a good communist is at the same time also a good Chekist (derived from 'Cheka', the first secret police organisation after the Russian Revolution). To enable the modern descendants of the Cheka to perform their function of total political control, roughly 500000 people are employed - of which a hard core of about 110000 permanent KGB officers form the 'Sword and the Shield' (their emblem). In addition to its own internal troops, the KGB has at its disposal five divisions of security troops, as well as some 2000 Kremlin Guards.

\section{World's largest}

For duty abroad, the KGB has at least five times as many agents as the $\mathrm{ClA}$ and all the Western European countries can field. At least half of USSR ambassadorial staff, as well as members of the Russian Aeroflot airline and trade-officials, military attachés, cultural commissars, technical and agricultural advisers are KGB and occasionally GRU (military intelligence) agents. Their never-ending task: to gather information about sensitive Western installations, to monitor and (where possible) to manipulate politicat trends, to infiltrate trade-unions, teaching establishments, churches and youth organisations and, of 
course, to promote communist revolutionary climates.

Before detailing some of the principal functions of the KGB, a look at the Soviet Union's political structure:
A KGB manual titled 'Organisation of KGB counter-espionage work' states that 'the determining factor in the espionage activity of the KGB is the foreign policy of the Soviet Government' (emphasis supplied). Any doubt about the origin and purpose of Soviet subversion is put to

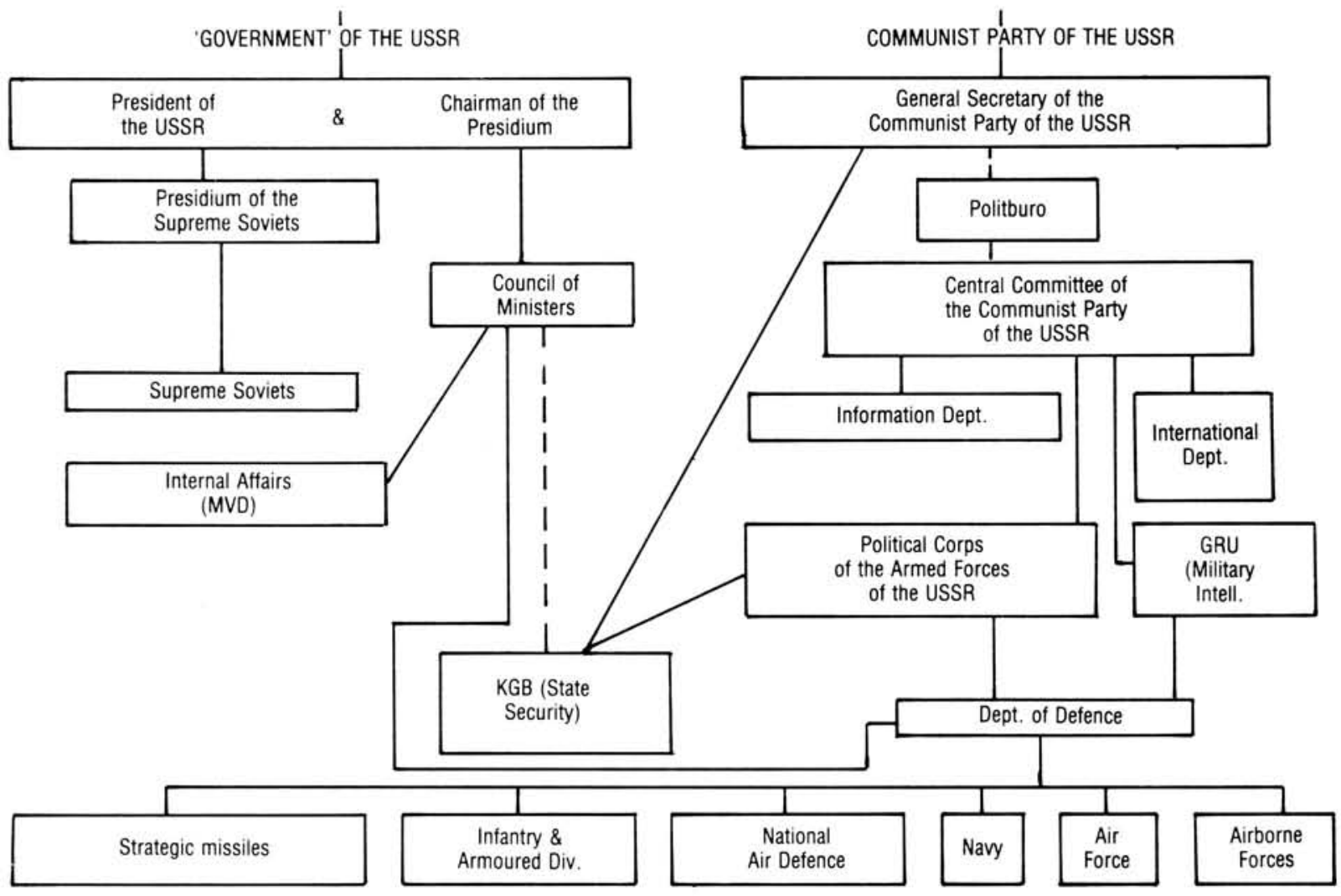

actual and direct

$\ldots \ldots \ldots$ Nominal and indirect

\section{Subversion as policy}

As can be seen from the above, the KGB is responsible to the General Secretary of the CPSU - whose ultimate sanction it requires for foreign operations involving governments or internationally sensitive issues. The 'Statute of the Committee of State Security' attached to the Council of Ministers of the USSR' explicitly enjoins the KGB to 'carry out espionage work in capitalist countries' ... and that its agents shall 'penetrate the state, political, scientific, technical and espionage centres of imperialist states ... with the aim of aggravating contradictions and difficulties occurring in their activities ... to give the enemy misinformation for political and operational purposes ...' Another directive: 'KGB organs are to carry out individual tasks entrusted to them by the Central Committee and the Soviet Government.' rest for good (Myagkov p. 31). Other specific Soviet Secret Police tasks include these: 'To set up secret control over both international and internal postal and telegraphic communications (and) to fabricate cover documents.' This directive is of importance to South Africa on at least two major counts: the recently founded PANA (Pan-African News Agency) and NWIO (New World Information Order) are obviously either 'useful idiots' or active fronts for the communists. Secondly, when French police uncovered a massive Soviet forging operation in the northern Paris suburb of Ivry (Sunday Times 29.6.80) it became evident that Henri Curiel, founder of the communist organisation 'Solidarité', had long produced fake passports and documents that discredited South Africa. Not only had he trained Breyten Breytenbach in the use of secret codes and provided travel documents for him under the 
name of 'Christian Galewska'; he also churned out great numbers of fake pass books for South African Blacks, maintained contact with Barend Schuitema, founder of the Dutch anti-apartheid movement and (just by the way) also counted Carlos the Jackal among his clients. The arrest of Curiel and his 6 'cobblers' (spy jargon for producers of fake documents) was, moreover, a heavy blow for the ANC, who had depended on them for defamatory and disinformationary 'documents' with which to discredit South Africa. All these underhanded shenannigans were initiated by S.A. Kondratchev, head of the KGB's department of disinformation - Dezinformatsiya - which was founded in 1959 as part of 'Disinfor- mation and Executive Action' of Chief Directorate Number 1.

It is well-nigh impossible to enumerate detailed KGB actions here. However, some indication of the massive scope of their subversive KGB operations can be gained by an analysis of the prime functions of the various Chief- and Sub Sections and Departments of the KGB, whose former boss was none other than Yuri Andropov, former General Secretary of the CPSU as well as President of the USSR and Chairman of the Presidium - and whose present head is V. Chebrikov:

\section{KGB Organigram:}

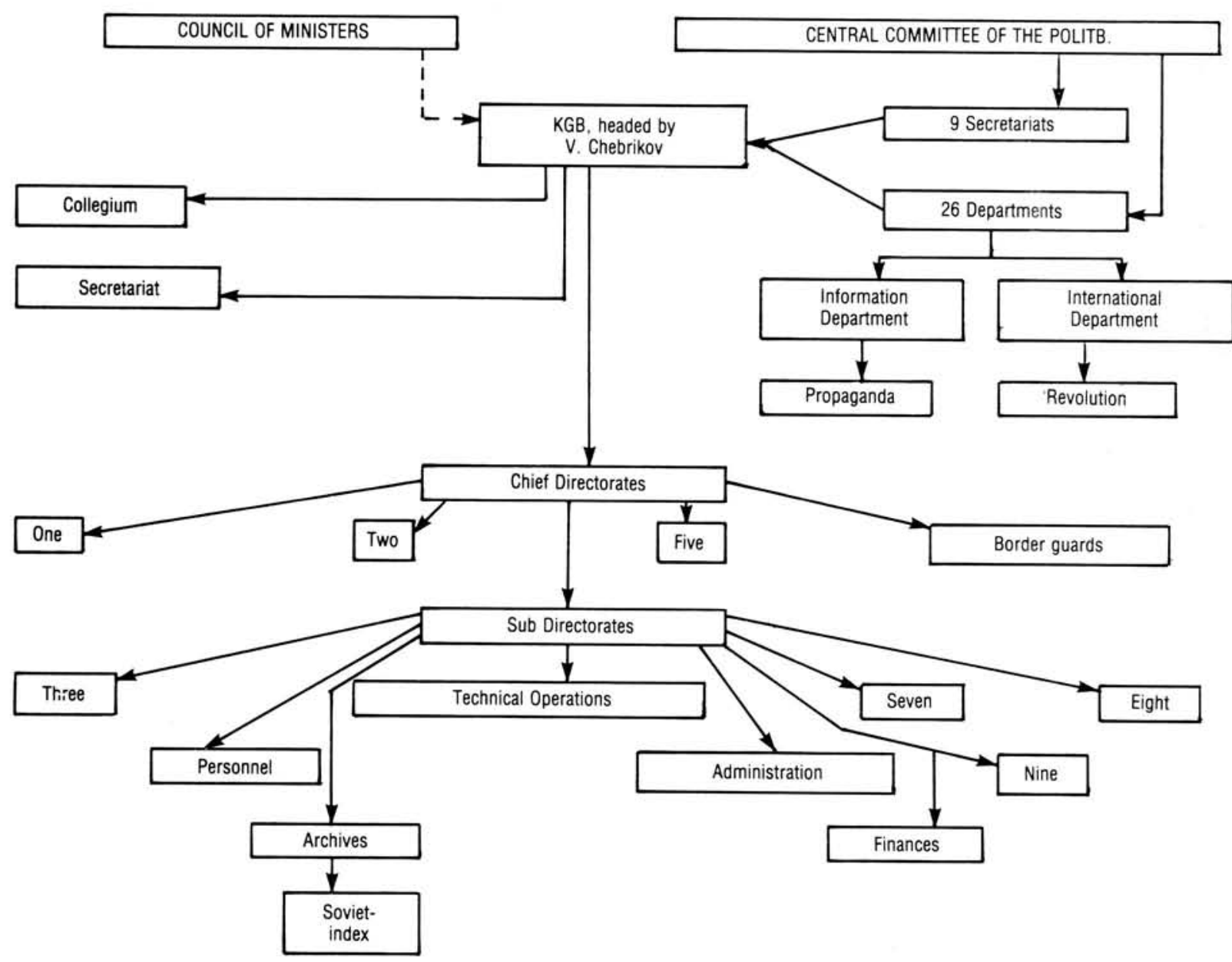


The above chart is neither complete nor static: compiled largely from Western intelligence sources and information received from KGB defectors, it is nevertheless a generally accurate reflection of status and structure of the various components.

Changes occur regularly inside the apparatus itself (since the days of the Cheka, the Russian secret police has been known as GPU, OGPU, NKVD, etc.) but its ultimate aims remain the same: the subversion, by any and all means, of the West and the world-wide communist dictatorship.

\section{Some of the principal tasks assigned to:}

\section{Chief Directorate No. 1:}

This directorate is sub-divided into 6 sections:

\section{(i) Section 'S' ('Sleepers')}

Here selected, capable and intelligent officers are chosen to undergo rigorous and specialised training which may last as long as 10 years. About 300-400 kilometres south-east of Moscow the KGB has fenced off several thousand hectares of isolated countryside. No one, not even top government officials, is permitted access to the area - unless specifically authorised directly by No. 2 Dzerzinsky Square in Moscow. This forbidden zone is subdivided into several units, each of which contains an exact replica of a typical Western 'town' containing a businesscentre, school, library, city-hall, police station and all the other official or social amenities one is likely to encounter in, say, a British or American set-up. It is not known just how many Western 'training facilities' are situated there (since each one is sealed off from contact with all the others) but it is likely that at least Western European countries, Britain and the USA are represented. Possibly other, non-European centres are also provided for.

'Sleepers' - so-called because such trained agents are infiltrated into target-countries, ordered to establish a local presence by becoming assimilated inconspicuously as professional or businessmen for a number of years, before the order comes from Moscow to 'awaken' them for specific tasks of espionage or sabotage - are given exhaustive instruction in the language, customs, religious practices, sporting preferences and at least two different types of trade or

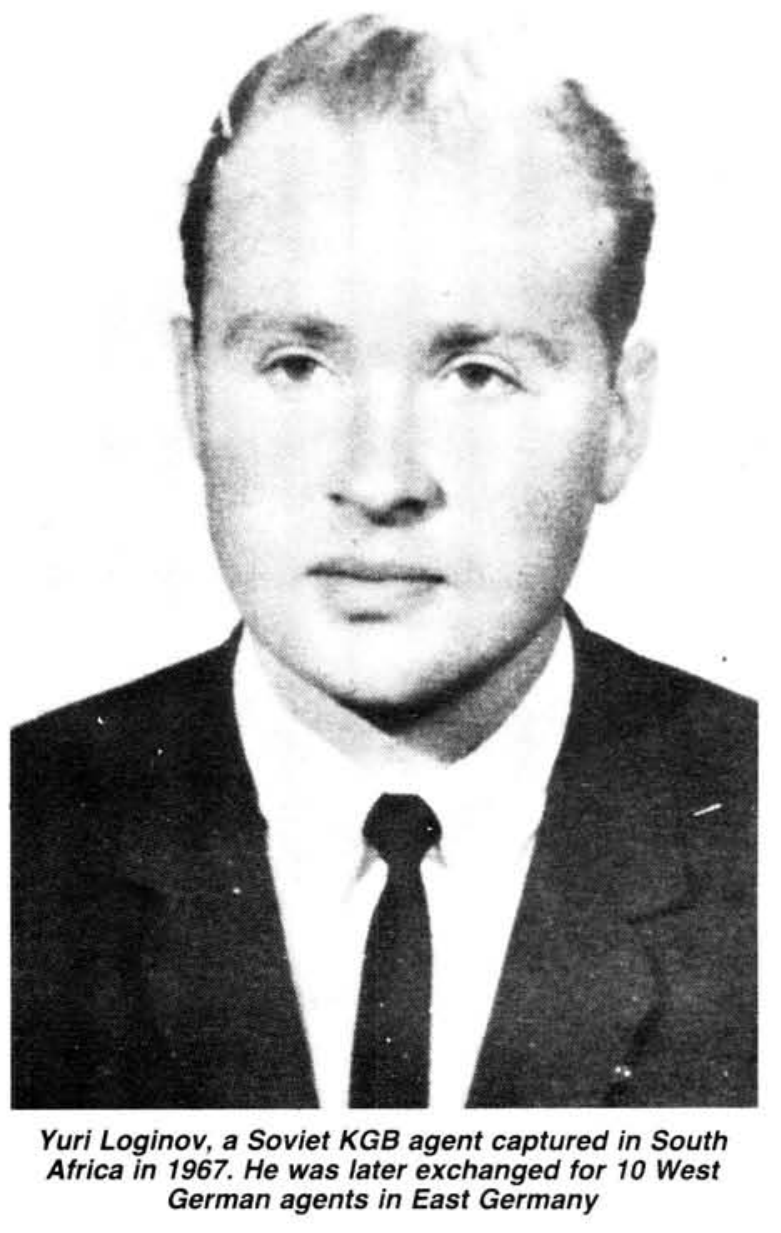

profession. Well-known examples of this type of operative are Y.N. Loginov (arrested in South Africa and freed in exchange for ten West Germans held in East Germany in 1968), Rudolf Abel (alias William Fisher) and, of course, Gordon Lonsdale (real name Conon Molody) arrested in Britain on evidence supplied by an East German defector in 1961.

\section{(ii) Section ' $T$ '}

Highly-trained technical and professional KGB personnel undertake data theft in the West. A recent example of their activity came to light when sophisticated computers were secured by a West German who had established domicile in South Africa, bought what was needed by the Soviets (in this case missile-tracking systems) had it transshipped through the RSA to a Scandinavian country for eventual delivery to the Russians. Fortunately the operation was uncovered and stopped in time. KGB-defector Myagkov, who visited South Africa a few years ago, suspects that West Germans are being used by the Russians in this country in preference to other nations. Obviously it would be a relatively simple matter for a hardened East German communist 
to pose as a West German after obtaining fake papers.

\section{(iii) Section ' 1}

Analyses data stolen (or legitimately obtained) from the West to determine its value and applicability to Soviet needs.

\section{(iv) Section Information and Counter-Intelligence}

This section serves a two-fold purpose: in cooperation with the GRU ('Glavnoya Razvedyvatelnoye Upravlenye') - USSR armed forces intelligence service - military and other strategic information is sought in the West through espionage and under cover of front organisations. The second major task entrusted to this section subsumes the total surveillance and control of Soviet nationals abroad, irrespective of rank or title. Its activities are mirrored in the USSR armed forces' Political Corps, which in turn is controlled by GLAVPUR (Main Political Directorate). The latter is sanctioned by the Defence Council, which gets its directives from the KGB itself. This intricate and inter-linked network of check, counter-check and cross-check has so far very effectively prevented the formation of anti-Party cells in the armed forces. As we shall see, political control extends from cradle to grave at home, place of work and even leisure-time of every single Soviet citizen. No-one, but no-one, countermands a KGB order that has been issued from $\mathrm{HQ}$ in Moscow. If the title 'Counter Intelligence' sounds unusual for the kind of work it here subsumes, it should be remembered that Soviet citizens, too, could be 'enemies of the people', i.e. of the communist party, and therefore require pre-emptive and 'corrective' treatment ... just in case!

\section{(v) Section Disinformation and Executive Action}

This is no doubt one of those undertakings the KGB would like to conceal from as many people as possible - not for reasons of moral niceties, but because its dirty tricks and bloody 'wet affairs' (assassination and ordinary murder) are not conducive to the KGB's 'good image' as 'guardian of the people'.

This section also has two main tasks - as suggested by the title: The 'disinformation' aspect encompasses domestic surveillance and control of foreign visitors. Among other functions - the systematic, co-ordinated and unremitting channelling of all non-Russians of whatever rank or title and on whatever mission to Russia. Student, businessman, technician, politician, diplomat or scientist - all are taken into personal custody by 'Intourist', whose 'guides' (invariably KGB personnel) see to it that foreigners are not only kept away from sensitive installations, but also that they are kept strictly apart from ordinary Russians. In the interests of the latter, it is just as well that this stipulation be adhered to; otherwise such citizens are immediately confronted and investigated for 'slanderous' or 'un-Russian' activities. At the same time visitors to Russia run a grave risk of being compromised by blackmail. Sexual enticement of the normal as well as the perverse variety are arranged by, among others, Intourist hotel staff. Illicit adventures are likely to be recorded and kept on file - sometimes for years, in case a victim attains the requisite status which renders him suitable for blackmail at a later stage. It is the explicit task of the infamous 'Soviet Index' department of the KGB to obtain information of this kind on as many Westerners as possible, and it is thought to contain biographical, statistical and deviant details of millions of people considered to be either 'enemies of the State' or amenable to blackmail on behalf of the USSR. There is tremendous pressure on KGB personnel at work in this connection to 'produce'; which means that the sheer volume of often manufactured 'evidence' is more of a reflection of the obsession with padding files, than it is of factual reportage. Nevertheless, this source for the subversion of likely espionage agents is unmatched by anything else anywhere.

\section{Smersh}

The 'Executive Action' part of this sub-section of Chief Directorate No. 1 is also known as 'Dept. Vee', continues the work of what used to be called 'SMERSH' (acronym for 'Death to Spies') during WW II. Apart from political assassination, KGB officers employed here are responsible for the infiltration, and in times of war or the imminent outbreak of hostilities, the destruction of critically important Western communications networks. The identification of transportation and control facilities, likewise - as well as their preemptive targeting and disruption - also form part of Dept. Vee's duties. KGB defectors have assisted Britain's MI.5 and Secret Service (MI.6) in the location of buried and constantly maintained communications equipment in various parts of England.

\section{0 die}

Other, very costly (in terms of human life) and very nearly successful disinformation and assas- 
sination programmes include the Indonesian experience during the 1960's (when about 90000 people were slaughtered by anti-communists who discovered the Soviet Union's attempt to install a Marxist government in Sukarno's place only just in time), as well as the Russian's attempt at overthrowing the Mexican government a few years later. Readers may recall the 'Yankee-gohome' hysteria that swept these countries at the time: all of it originated in this department.

\section{(iv) The last sub-section of note in Chief Directorate No. 1 is known as the 'Normal Dept'}

Divided into 10 so-called 'cultural zones' of geographic areas of the Western world such as Western Europe, Britain, the US, for example, each area is ministered to by suitably-trained KGB officers who operate through a bewildering array of front-organisations: South Africa falls under area No. 5, and is the recipient of the unwelcome attentions of no less than 76 United Nations organisations, committees and councils who either directly or indirectly seek to undermine the RSA. For the record, UNESCO (one of the major organisations among the 76) is totally infiltrated by the KGB - hence the decision of the United States to withdraw its support from UNESCO altogether by the end of 1984: this is hardly surprising since the West pays the lion's share of that organisation's budget - for the privilege of being undermined by it.

The KGB also makes its presence felt in the World Council of Churches. The Russian Orthodox (in Russia) member church's primate Nikodiem is a KGB appointee - in addition to which the Russians vetted the top posts of the WCC itself. More than one personal assistant of the UNO has been a known KGB agent into the bargain.

A final task of this subsection concerns the manufacture of fake and defamatory documents, as well as the development and use of lethal chemicals and other instruments of murder.

So much for the activities of a single directorate of the KGB!

\section{Chief Directorate No. 2}

Here we have to do mainly with the control of Russian nationals inside the USSR. Since the 15 republics of the Soviet Union are by no means all constituted of Russian elements (there are 20 major language groups, and over 100 dialects are spoken) dissidents are, as exemplified by Afghanistanis, not uncommon and require strict and frequently harsh control to keep them in line with official Marxist doctrine and communist party directives. Such political suppression spills over into purely domestic matters as well: unreported or little-known internal uprisings have taken place inside Russia and have been bloodily suppressed by troops firing into crowds at Alexandrov (1960); Novocherkassk (1962); Ryazan (1964); Chimkent (1967); Khorol (1968); Dneprozherzinsk (1972) as well as at Ivanov not long thereafter. Every one of these 'provocative riots' which precipitated action against 'antiState elements' had to do with crowds who protested about food shortages.

\section{Non-Russian army}

It is clear that people who feel hatred and resentment against the Russian communist dictatorship inside that country are seething with frustration. The numerical preponderance of non-Russians will be an indisputable fact by the year 2000 - which means that the recruits drafted into the USSR's armed forces are already close to $50 \%$ of the total now. Resisting forcible assimilation, non-Russians are proving to be possibly the gravest headache the USSR's Politburo must come to terms with: consequently harsh repression is the order of the day the moment nationalistic or religious sentiments manifest themselves. The danger of all this is, of course, that the Soviets not only continuously foment revolution abroad in order to detract from their home-grown problems - but, even more ominous, the realisation that time is running out for them may force their hand and precipitate hasty and potentially catastrophic pre-emptive measures. (Indeed, quite apart from the growing communist Chinese threat, many other factors add up to an expanding compendium of intractable issues: nationalism - just mentioned, diminishing energy resources, growing Western perception of Soviet subversion, geo-strategic disadvantages, the likely refusal of Warsaw-Pact allies to commit themselves fully to their Moscow masters in time of war, the eroding credibility of communism among Asiatic nations - plus a few others). One way or another the Russians only resort, viz. further lies, violence and suppression, cannot be maintained indefinitely as a viable option against human desires for self-determination and freedom. Hence, the vicious circle of increasing resistance to increasing KGB harshness must ultimately lead to its demise - either through attrition or voluntarily. It is unlikely at this stage that the 
latter option will be exercised by the communists, since it would destroy them from within. As the wise old Chinese saying goes: He who rides the tiger dare not dismount! Even more to the point: he who wields the sword shall perish by it...

\section{Slave labour}

Chief Directorate 2 and Chief Directorate 5 obviously conduct certain operations which overlap: the latter's administration of the infamous 'Gulag Archipelago' - about which Aleksandr Solzhenitsyn wrote so eloquently, having spent years in a slave-labour camp himself - and the suppression of minorities inside Russia testify to that. More about No. 5 later.

Other functions within the preserve of No. 2 include the maintenance of industrial safety, not as in the West, concerned with prevention of accidents, but with the control of sabotage by disaffected workers. The standard Russian attitude of 'Since the State pretends to pay us well, we pretend to work hard' is not surprising in view of the fact that private initiative and the profit motive are strictly taboo. Another KGB task in this subsection: the surveillance of Soviet trade-missions abroad. To round off the list: subversion and recruitment of foreign diplomats inside the USSR; the investigation of corruption (a rich one, that!) and wastage of State property; and finally the operations of a group known as the 'technical support group' (in fact a fraternity of professional burglars). Of course the sentence for 'economic sabotage', which may cover any of a multitude of sins for which Russian citizens are answerable to Chief Directorate No. 2, is death by firing-squad. Executions do not appear to be regularly reported by the likes of 'TASS', but they do still take place.

\section{Chief Directorate Border Guards (not numbered)}

Consisting of approximately 300000 men, most of whom are under arms, this KGB organisation is tasked with the security of the USSR border. It is a formidable undertaking. As the largest political unit in the world, the Soviet Union has a coast-line of about $16000 \mathrm{~km}$, as well as a frontier of about the same length to guard (the USSR abuts on 12 countries). Internal geographic dimensions are, approximately, $10000 \mathrm{~km}$ east to west, and 4,500 km north to south. These areas and borders are not, however, imperiled by aggressive intent from abroad. On the contrary, they contain the peoples of the 15 so-called 'autonomous republics' of the USSR - peoples who would (if they could) leave Russia by the millions. It is up to the CD Border Guards to prevent such flight from the Worker's Paradise. The counterparts of the Russian KGB Border Guards are to be found in Soviet satellite states as well: the East German Mfs (Ministerium für Staatssicherheit) is responsible, through the HVA (Hauptverwaltung Aufklärung) for the maintenance and manning of the Berlin Wall which has cost the lives of many people trying to reach the West. Control along communist borders is ruthless and efficient: anyone venturing near forbidden zones is shot, blown up by landmines, shredded by triggered shrapnel, torn apart by dogs or reported to the KGB by frightened locals who are conditioned by the simple expedient of being 'suspected of assisting anti-Soviet elements', should an escape succeed. The Mfs (as well as all Soviet satellite states' security police) are subject to KGB surveillance in some measure. Of course, citizens of the Soviet Union are free to get in touch with the KGB themselves, should anything trouble them. The Moscow telephone number: call 221-07-62 for 'Enquiries' at the 'Pervy Odtel' (First Department)!

\section{Chief Directorate No. 5}

Some of the activities of this directorate strain the imagination, and border on the Kafkaesque.

Apart from liaison with CD No. 2 in respect of the control of political minorities and the consequent overlapping and duplication of the tasks of these two Chief Directorates, CD No. 5 has several very specific orders. Some of these concern:

\section{Psychiatric torture}

(i) The staffing, maintenance and operation of psychiatric institutes for the purpose of 'curing' certain 'paranoid reformists' i.e. people too wellknown or important to warrant summary incarceration in the Gulag, there to rot and be forgotten. No one is immune. Mother Russia's military heroes (like Marshall Grigorenko, one of the most decorated officiers of WW II), researchers, scientists, writers or whoever, are visited by the KGB the moment they manifest anticommunist tendencies - such as a public demand that the Helsinki Accord be implemented as underwritten by the USSR itself. Grigorenko - a communist, yes, but a man of integrity nonetheless, was arrested on Red Square after protesting that the USSR constitution's rights (such as they are) were being withheld from people by those who were supposed to guarantee them in the first place. For that bit of effrontery he was bundled off to the Serbsky Forensic Institute of Psychiatry in Moscow and delivered into the hands of KGB 
Colonel D.R. Lunts, who donned a white coat and became 'Dr' Lunts, and diagnosed 'schizophrenia of the paranoid type'. Subsequently the Marshall was transferred to an assylum at Chernyakhovsk. His political 'condition' was treated by mind-bending injections of Pentathol and other suitable means - in order to extract a confession from him that he had erred. When that failed, he was declared insane. According to evidence collected by author J. Barron in his book 'KGB', many hundreds of healthy, but anticommunist or 'revisionist' citizens have suffered (and very likely still are undergoing) this kind of 'therapy'. In Stalin's time, of course, such refinements did not exist and would have been deemed extravagant since a bullet provided a far more rapid and permanent solution to problems of State. These days summary executions and the dreaded midnight-knock have been largely superseded by more sophisticated methods like these. Today, as in Lenin's time, the 'scientific use of terror' still prevails.

\section{Censorship}

(ii) The total literary control of every single document, book, film or tape issued in the USSR. 'GLAVLIT' looks after the 'ideological purity' of the written, printed and spoken word and vigorously combats all 'Samizdat' ('self-publishing') copies of forbidden, and therefore underground, publications. KGB officers see to it that every duplicating facility - such as copying machines - are kept locked at all times when they are not physically present. A literary writer's guild, subservient to official Marxist doctrine, lavishly rewards the likes of Ilya Ehrenburg and Mikhail Soiokov whose third-rate and frequently plagiarised books extol the virtues of the "new Soviet man' as he flings himself into joyous labour and ever-increasing overproduction of set norms, or depict the glories of communist military and police adventures against renegade White Russians who resisted Lenin and Stalin.

\section{Jews pay to leave}

(iii) Thirdly, there is the Department of Jewish Affairs. Its main preoccupation: the processing of emigration applications. Depending on Western outcry or political expediency, $x$-numbers of Jews are allowed to leave. However, engineers and other professions are expected to reimburse the State for costs incurred during their education in Russia. The going rate for an engineer: approximately 10000 roubles (more than R10 000). The control of synagogues falls under the next, and final sub-section of Chief Directorate No. 5.

\section{Fake 'priests'}

(iv) Probably no other KGB activity in the realm of disinformation is quite as objectionable to noncommunists as that which falls under the 'Department of Religious Affairs'. It is, moreover, also one of the most dangerous and potentially successful subversions of the human spirit imaginable: we have here to do with nothing less than the systematic and very thorough training of bogus priests. Just as the Patriarch of the Russian Orthodox Church in Russia (not to be confused with the Russian Orthodox Church abroad, which is staunchly anti-communist and has its own head) is a KGB man who transmits whatever 'anti-Soviet' confessions he is privy to to No. 2 Dzerzinski Square or its appointees, the churches abroad are also catered for. As we have seen, the WCC (World Council of Churhes) too, is beholden to the communists. But, infinitely worse are the diabolical activities of the 5 establishments which train ministers of various denominations at:

(a) FEODOSIA, in the Krim. Here chiefly Latin countries are the ultimate recipients of fake Catholic 'priests' who are educated in the history, ecclesiastical custom, ritual and doctrine of that Church - before they are marked for infiltration into religious communities of target countries: France, Italy, Portugal and Spain.

(b) Likewise, 'priests' are produced in LVOV (also known as LEMBERG) in the Ukraine for Switzerland, Belgium and certain South American countries.

(c) SIGUEL (also SIGULDA) in Latvia caters for Germany, Britain, Austria, the Netherlands and Scandinavia, while

(d) MOSCOW is the centre for ministering to Canada and the USA.

(e) Finally, KONSTANTA in Rumania specialises in Eastern faiths such as Mohammedanism, Buddhism and Hinduism.

\section{Christ as revolutionary}

After 6 years of intensive religious, linguistic and target country training for their 'ministry' abroad, little controversial preaching is done, but by subtle stages congregations become radicalised and politicised against their country's governing authorities. Since a person's religious convictions are of central importance to him, and not infrequently constitute the Achilles Heel in matters of doctrinal manipulation, successful subversion is virtually guaranteed among at least some of the people who believe sincerely that the humanist and 'liberation theology'-approach holds great promise of freedom for the domestic masses that are exploited under capitalism. From there it is but a few short steps to the taking 
up of arms, as indeed certain South American Catholic priests have already done in order to 'hasten the coming of the Lord'. Christ is portrayed as the Revolutionary par excellence, the here-and-now is considered to be as important (or more so) than the hereafter, and 'human rights' and 'freedom' are defended by bombs 'if necessary' - since violence is 'cathartic'. These grotesque perversions are not all that difficult to understand when one considers that violence is being celebrated in itself on many other grounds as an acceptable solution to problems which will not yield to other methods of persuasion. The military, police, entertainment, literature, TV, radio, universities, trade-unions all in some way contribute to a perception of violence as a substitute of the consultative process instead of as its negation. That law and order and the legitimate defence of a country's sovereignty require violence occasionally, is disallowed as an 'infringement' of the rights of people to 'do their own thing' - including the refusal of national service on religious grounds. Small wonder that immature and apathetic minds are swayed by such rhetoric, particularly if it emanates from a priest...

\section{The church \& subversion}

It should be apparent that 'the Church' is becoming an increasingly docile and handy vehicle for communist indoctrination. As in democracy itself, the seeds of its own destruction are sown within it: the right to worship has been so subverted that it has become (and, sadly enough, accepted as) a political weapon. 'Salvation' and 'liberation' are almost synonymous in the liberal theological mind. And it is precisely this which the KGB 'priest' knows how to exploit and cultivate. It is also this which wellmeaning liberals (who would be horrified at any KGB connection) unwittingly propagate in their attack on national service and government authority as the so-called 'immoral' exercise of power. Perhaps the Namibian Council of Churches and the South African Council of Churches would care to comment...? In all fairness, they should be given proof of the above: Monsignor Tondi, long-time assistant to Pope Paul VI, was caught as a spy in the Vatican. Before he fled to East Germany, there to head the 'Department of Religious Affairs', he boasted that he had been a communist for many years.

\section{Subdirectorates}

Subdirectorates of the KGB are engaged in more 'passive' pursuits. Thus No. 7 personnel is geared for the surveillance of dissident elements abroad: emigrés, particularly White Russian organisations, are a prime target. Subdirectorate No. 8 undertakes the monitoring and deciphering of space-satellite information, while No. 9's exclusive task is the guarding of high communist officials: only KGB members of this subdirectorate may carry arms in the vicinity of government or party leaders.

Administrative and financial affairs are also handled by subdirectorates. Perhaps it would not be far off the mark if one were to view most of them as support facilities for the Chief Directorates.

How does the Soviet propaganda machine work in practice?

\section{International Communist Propaganda: its origins and front organisations}

The single most important tool of communism is, of course, violence. Violence, however, has two parameters: the physical and the mental or spiritual. In other words, physical coercion and propaganda together force the issue.

Propaganda, in turn, is built on deception: lies, truths and half-truths are selectively employed to propagate a given 'Weltanschauung', to impart credibility to it. Facts, therefore, are in themselves meaningless - they need to be interpreted in a certain way. This distinction between mirrors of truth and interpretation or manipulation of truth marks the difference between democratic and autocratic purpose: on the one hand, a neutral legal system that adjudicates differences between contending interests; on the other a biased legal system as instrument of power in the hands of a section of the people.

\section{Justification of terror}

In communist societies, however, even the opportunistic must somehow try to 'justify' their programme. Put differently: their principle-of-noprinciple becomes a principle in itself. The important thing to communists is that doctrinaire grounds must be fabricated for actions that ignore the rights of the individual. His dissenting voice must be stilled in the name of the 'larger whole' of which he is only a 'small part', viz, the State. For that laws are needed - laws whose prescriptive and proscriptive content and intent leave little doubt in the minds of those individuals that the totality of the nation (and by extension, the totality of mankind) immeasurably exceeds his or her little selfish interests. To bring home this 'truth', the State exercises sole discretionary 
fiat. With apologies to Jean-Jacques Rousseau: the people must be made to see the folly of pursuing fanciful 'rights' while their real and rational rights repose in the State, their 'curator bonis'. It alone presides over the sum-total of everyone's dispensation.

Having established that, communist doctrine can justify just about anything. The State in its wisdom does not make mistakes: present suffering and shortages are ultimately all to the final good. After all, if every citizen would be permitted to do his or her 'own thing' we would have chaos - not so? Control and authority are necessary adjuncts of the revolutionary process which must in the end lead to the liberation of all peoples from exploitation by some among them. Q.E.D.

\section{Morality \& profit}

Morality, then, is a bourgeois invention and convention encouraged by the capitalists whose instrument is the church: the profit-motive will (in the name of a spurious 'personal freedom') remain alive and well as long as people are conditioned into accepting their servitude as part of a Biblically-ordained and sanctified right to private property. Such, at any rate, goes the MarxistLeninist litany in its attack on private ownership.

Coupled with the right to private ownership, we have the right to vote governments - who are expected to administrate our rights according to a law that transcends even their authority - into or out of power. To the communist, this practice is nothing but the relentless and ever-increasing consolidation of power of the have's over the have-nots. In other words, Western democracy creates licence to exploit unashamedly. And since such governments are beholden to the business-interests which put them into power in the first place, they actively entrench a permanent worker inferiority in every way. To the un- or undereducated, the disaffected and the uncriti$\mathrm{cal}$, the latter type of argument sometimes holds powerful emotional appeal. What has a shantydweller to lose by assisting in the liquidation of his 'oppressor'? If his precarious existence and deprivation are symptomatic of capitalism, why, communism couldn't possibly be worse, could it? And the seeds of revolution are sown...

\section{Half a picture}

What is conveniently omitted by the Marxists is, of course, the other half of the picture: the poor are not poor as a result of official decree: they are not forbidden to improve their status in a nonpredatory manner. Free education and excellent social services are available to those who ask for it if they cannot pay. This can hardly be said of, say, the Soviet Union where the communist party and its armed executors of policy have the sole jurisdiction over every single aspect of every citizen's life from cradle to grave, and can therefore determine the material lot of any given person. Nor are the nominal adherents to official communist doctrine exempt from such control: only unquestioning loyalty to the cause ensures their relatively prosperous survival. Hence, communism can at one and the same time exercise total control over adherents as well as non-adherents of the party.

\section{Conform - or go under}

Taking these considerations into account, we must now look at some of the characteristic practical aspects that flow forth from them. In the first place, trust and loyalty are utterly self-centred, as they have to be if communism itself is to survive. Cynicism is, however, the sole preserve of those who have made the grade: young hopefuls are rigorously indoctrinated with the imagined advantages of official policy even as they must surely perceive its failures all around them. The important thing, ultimately, is to establish the reality of centralised authority: that it has its shortcomings is accepted, but largely blamed on the weather (droughts, poor crops) or other outside forces which seek to undermine communism (the suppression of the workers internationally by capitalist exploiters). Eventually it follows that the up-and-coming young aparatchick has one of two choices: conform or go under. There is no third alternative. Trapped by the system he shall suffer one way or another if by either omission or commission he fails to support it: should communism go under, he will go down with it. Should it survive in spite of his opposition to it, he will also go under. Thus, whether it be a perceived threat from the West, or from inside his own ranks in the party, he has no option but to continue to defend what imparts power and privilege. Only very, very rarely does one hear of an influential and/or committed communist inside the Soviet Union who has a complete change of heart and airs it publicly. Once again, communism and complete self-interest are bound up by a virtually indissoluble symbiosis. After all the verbiage and learned claptrap have been dispensed with, this is the rock-bottom foundation of the system which confronts us - and we had better remember it!

\section{World-inflation}

From the foregoing it follows axiomatically that ALL and ANY communist offer of 'detente', 'armistice', 'peace' or 'disengagement' cannot possibly be taken at face value. Any of these are, 
with apologies to von Clausewitz, war by other means. This being so, it behoves South Africa to exercise the greatest circumspection in respect of Soviet willingness to negotiate. The USSR never negotiates for the sake of an equitablybalanced outcome - it does so only to consolidate or to gain time. Whatever the reason, the West is sure to be the loser - as it has been all along even before Potsdam and Yalta, and most certainly thereafter. Only one thing impresses Soviet (and other types of) communism: power, coupled to the resolute will to resist. Nothing else finally matters in the East-West struggle for supremacy. That is to say, only a refusal to come to terms with communism will ensure our survival. We bargain with them at our peril!

Who, then, are some of the exponents of this fine art of supremacy at any cost? It would be cumbersome to enumerate all the members of the Politburo or the Supreme Soviet, but some of them - and their subordinates - should be mentioned inasmuch as they affect South Africa.

\section{Politburo, Central Committee of the CPSU and the ID and IID.}

In theory responsible to the $\mathrm{CC}$ (Central Committee) of the CPSU (Communist Party of the Soviet Union), the Politburo nevertheless enjoys a high level of autonomy and often initiates programmes. The number of its Secretaries varies between 8 and 12, each of which is responsible for one or more of the 26 departments of the CC. Departments, in turn, are headed by Dept. Chief, First Deputy Chief and Chief.

The authority of Departmental Chiefs exceeds that of Ministers of the Council of Ministers, headed by the Presidium and, above it, the Chairman (and usually President of USSR as well) of the so-called 'government' - as opposed to the Party - of the Soviet Union.

\section{SA a priority target}

The Politburo, on whom some Ministers are represented as well (Gromyko, Ustinov and Tikhonov), directs the activities of two bodies which are of paramount importance to South Africa. They are the International Dept. (ID) and the International Information Dept. (IID). The former is responsible for the export of revolution abroad, the latter handles propaganda and disinformation against Western and other target nations. South Africa is high on their list of priorities - of that all of us may be quite sure!

The Head of the infamous International Depart- ment is Boris Ponomarev. Founded after the former Comintern was disbanded in 1943 as a sop to temporary Western allies who objected to being undermined by the Russians even as they assisted their war effort against Germany, but reactivated later as the 'Foreign Affairs Dept.' until it became the ID. This specialist organisation has since 1957 been used as a tool of Moscow's foreign policy. Ponomarev and his deputy, R.A. Ulyanovsky, control its four divisions: 3 Africa and 1 South Asia. Both men are knowledgeable about Africa and rated as experts on so-called 'national liberation movements'. The present section chief of the Southern Africa division is thought to be V.G. Tolstikvo.

\section{KGB service academies}

Publishers of the World Marxist Review, which is the mouthpiece of the CPSU, the ID is also responsible for liaison with non-ruling communist parties world-wide, as well as with a few ruling ones. One would think that Gromyko, as Foreign Minister, would be tasked with policy discussions concerning South Africa. In fact, Ponomarev sits in on all such committees concerning Southern Africa and terrorist movements active there. The 'Soviet Co-ordinating Committee for Africa' is in constant touch with Joe Slovo (through the SA Communist Party) and the likes of ANC leaders. Much of the research done in connection with the RSA and its neighbours emanates from the Institute of International Affairs in Moscow. The latter is a service academy for the KGB.

The IID, whose head is B. Zamyatin, is a typical reflection of Soviet political schizophrenia: while party propaganda for home consumption is heavily orthodox, rigid and hostile to most things foreign, that destined for consumption abroad abounds with aggressively populist sentiments which question the need for 'fascist' government control and vilify national service. The civil disobedience and outright revolutionary activities which are encouraged elsewhere, would result in instant deportation to the Kolyma (Siberia) or execution back home in Russia. Soviet propaganda, need it be said, tries to destroy freedom in the name of freedom.

\section{Pecking-order}

For the home market, other KGB agencies seek to instil iconographic fervour (the worship of pictures or images) in the people: pictures of the 'Vozhd' (leader) saturate the entire USSR in their millions - only to disappear overnight should he fall into disgrace or die. By the same token, Kremlin-watchers can determine very accurately 
the exact stature of leaders' authority by observing standing arrangements on the Lenin mausoleum in Red Square, or by looking at official photographs and portraits. That, too, is part of the communist Messianic and collectivist vision: everything is done according to plan and every plan must have the approval of higher authority.

\section{Propaganda}

The ID's World Marxist Review (on which sit about 60 representatives of foreign communist parties, and which is based in Prague) is published in 37 language editions. Together with the IID's 'agitprop' (political agitation), it plays a large role in the constitution and financing of socalled 'peace movements' like ban-the-bomb protests. But overt and cultural issues are also published. Zamyatin, who is also General Secretary for the Politburo's international communications, sees to it that the USSR's most important voices are amplified: Chernenko and Gromyko therefore presently determine much of the tenor of Soviet propaganda. ${ }^{\star \star \star}$

There are three more or less defined Soviet 'information' types: the 'white' (handled by the IID and the Foreign Ministry), the 'grey' - responsibility of fronts, parties and movements run by the ID, while 'black' is catered for by those who know it best: the KGB. It is thought that Soviet propaganda expenditure runs to approximately 35000000000 roubles annually. A portion of this goes to the financing of 'rent-a-crowd' expenditures (cf. 'Propaganda': A modernised Soviet weapons system, by P.A. Smith, Jnr., Strategic Review, Vol. 2, No. 3, 1983).

\section{World communist parties}

There are 96 recognised communist parties in the world today: of these, 80 are non-ruling, and under the control of Ponomarev. Of the estimated 77 million party members (including 39 million Chinese) which have a controlling say in the running of 16 countries, many are in one way or another engaged in subversive activity or are directed towards the suppression of freedom of expression. Their task would not be possible without being able to infiltrate Western institutions by means of front-organisations.

\section{Shifting emphasis}

Of course, not only Western countries are thus subverted: Asian, African and South American as well as Central American countries have also attracted the unwelcome attention of the purveyors of communist disinformation, but Third World nations are not accorded the intense and

$* \approx *$ Suslev, C.P.S.B. idealogue, was - until his death - in charge of most of the official communist doctrine's formulation. costly effort which is directed at, say, Western Europe. Since France, for argument's sake, possesses a credible nuclear deterrent it is that much more dangerous for the Soviets. For this reason, the highly industrialised peoples are subjected to unceasing propaganda in various guises. Communist parties organised over 70 protest demonstrations there in 1981 alone. The shift from gross lies and distortions is also perceived by leading Western analysts. The Deputy Director of the CIA sees these trends developing in the immediate future: 'Greater attention to security, disarmament and peace issues ... a tactical de-emphasis of communist ideology, greater operational sophistication in the manipulation of influence assets and in the production and use of documentary forgeries; greater willingness to work with religious groups and non-communist political parties ... communist front organisations ... allies, proxies and surrogates such as Cuba, continued opposition to Western ... social and economic influence in the Third World, and greater advocacy of the creation of new international institutions and organisations such as a Third World Press service that promotes Soviet influence.' (P. 38, Pacific Defence Reporter June 1983: Valerij Ivanov and company, by H. Handleman.) The foregoing would appear to be a rather accurate reflection, considering that all of these projections have already come to pass.

\section{Abusing protest}

It should be made clear here that not all antinuclear organisations are necessarily communist, and that their exploitation for communist propaganda purposes is disliked by them. The same applies to other humanitarian institutions, committees, and so on, active in various fields. Unhappily, however, groups like the Greenham Common Women in the UK protesting against the stationing of American missiles on British soil, find themselves expressing the Kremlin's views on the so-called danger of nuclear escalation: for that reason these women figure prominently on Soviet TV and in the communist press as 'courageous anti-imperialist fighters'. It is likely that S.A. Kondratchev of the KGB Dezinformatsiya Dept. collaborates with Zamyatin of the IID, and that persons like Solodovnikov, former USSR ambassador to Lusaka and Salisbury ( $\mathrm{Ha}$ rare), see to it that anti-RSA programmes get off the ground: the latter, after all, used to employ 400 workers whose overriding function it was to garner information about the RSA and SWA, and to liaise with SWAPO and the ANC as well as Joe Slovo. This linkage with non-communists to the communist cause creates the impression that, 
say, the Greenham Common Women and the ANC work for the same cause.

\section{West slow to wake up}

Western attitudes towards this mortal danger inherent in Soviet subversion are at times difficult to fathom. While leaders like President Carter of the US tried the moral imperative as bait with which to shame the Soviets into desisting from their aggressively imperialist stance, and forbade the CIA and the FBI to combat the Russians effectively by imposing all sorts of restrictions on them, the USSR had no such compunction. KGB and GRU agents are stationed at the United Nations (The Economist estimated as far back as 1976 that probably 180 or so were in place), to which the FBI is legally denied access. KGB agents - some 39 are also stationed at the UNESCO HQ in Paris, while about 50 work at the ILO in Geneva, Switzerland. They can also be found at the International Atomic Energy Agency in Vienna. In effect, then, all these formerly 'neutral' organisations have been converted into fronts for the Soviets. Let us look at some of the better known and try to understand why G. Dmitrov of the old Comintern already realised that communist sympathisers (i.e., noncard-carrying ideological fellow-travellers) are each worth '100 card-carrying, militant communists':

\section{Communist front organisations}

The World Peace Council (WPC), World Federation of Trade Unions (WFTU) World Federation of Democratic Youth (WFDY), International Union of Students (IUS), International Association of Democratic Lawyers (IADL), International Association of Journalists (IAJ), Women's International Democratic Federation (WIDF), and the World Federation of Scientific Workers (WFSW) in addition to the more recently created NWIO New World Information Order, are some of the more obvious Soviet Front organisations. The problem is that these and others in turn spawn second- and third-generation fronts whose affiliation with Moscow becomes obscured. Hence they are in an ideal position to attempt the subversion of members of the USA Congress, for instance, who need no security clearance in order to gain access to classified information or to infiltrate educational, religious and recreational groups anywhere in the West or, for that matter, in the RSA.

\section{Infiltration of UNO}

Apart from blatant fakes such as the above-mentioned 'World Federations' et al., there are, of course, also many other disinformation sources:
USSR delegations to the UNO and other international organisations, correspondents of Tass, Izvestia, Pravda, etc., Armtorg purchasing commissions, Aeroflot crews, Warsaw Pact collaborators and Soviet 'academic' institutions. Occasionally some of this tide of filth and lies washes back onto Russia's own propaganda shores, there to create confusion: an American delegate to a SALT meeting was asked by his Soviet counterpart not to bandy about too many USSR secrets since some members of their own delegation 'were not cleared' to be privy to them; obviously some are considered to be too frail to endure the truth, or else the Soviet delegate could no longer distinguish fact from fiction in his own position-paper!

\section{Suitable traitor-material}

It would not be out of place to list what the Russians themselves consider to be suitable categories for pro-communist work: amoral government employees, lonely secretaries, spoiled brats and disaffected intellectuals. Unpromoted and unpromotable military personnel could also figure among this rogues' gallery. In short, greed, lust and resentment are fruitful emotions to exploit.

\section{"Non-aligned"}

In the Soviet set-up, 'secrecy' and 'security' are virtually synonymous. This means that the truth and insecurity are, likewise, allied. Indeed, in any communist system, the truth - both good and bad - is never neutral. For, nothing - no event, no human being, no pursuasion - is ever noncommital in communist eyes: you are either for them or against them. There is no falling between these two. Professed 'non-aligned' states, therefore, are considered to be enemies unless and until such time as they become 'progressive', i.e. sympathetic to the USSR. Which is precisely what has happened in international politics: "nonaligned' nations are invariably pro-Soviet or at least anti-Western.

This cavalier attitude towards terminology in the political sense has an Alice-in-Wonderland quality about it: the communists like to determine what words, promises, conditions and clauses shall mean under given cirumstances. Consequently, what was valid yesterday may no longer fit into the scheme of things today: as a matter of fact, Soviet 'history' is rewritten whenever it suits the ruling clique to do so. Once upon a time Stalin was the invincible giant; after his death he was suddenly discovered to have been a brutal tyrant. These days there exists a kind of ambivalence about the dictator: some Russians feel that a bit of rehabilitation would be in order. In the 
'Vozhd's' time, so the saying goes, things would not have been permitted to deteriorate to such an extent...

\section{Discovering "enemies"}

One is bound to wonder what all the incessant propaganda, all the lies, all the violence, are supposed to achieve in the long run. The answer probably is that the ever-present fear of 'counterrevolutionary' activity drives communist rulers to paranoid lengths in their frenzy to discover 'enemies of the State'. One of the obvious methods with which to combat that enemy is to confuse him: a judicious admixture of truth, half-truth and lie is far more effective than any straightforward untruth. The latter can, after all, be disproven while the former is very difficult to disentangle. Moreover, once some truth is found to be part of a given disinformation programme, unease persists in the target-group that there just might be more truth to it ... This is, of course, a muchfavoured method of communist propaganda against the RSA, as is evident almost daily from the reports emanating from the UNO. The problem with this kind of half-truth or lie is that it forces the target-group or country onto the defensive. In addition, any denial of an accusation somehow does not carry the same weight as the accusation: an implicit suggestion of guilt lingers. It is a supreme irony that Marx's vision of capital concentrating in fewer and fewer hands in capitalist countries, has in fact also material- ised in communist countries. Much the same can be said about the truth in the latter instance.

Thus, the Russian NOVOSTI News Agency which is responsible for the co-ordination and dissemination of all anti-Western propaganda out of Moscow, is the great generator of guilt which it then 'exposes' - much as the KGB does inside the Soviet Union itself.

Since communism depends on unrest and instability which provide it with the pretence needed for intervention, as well as that required to justify its growing might, its adherents cannot afford to let peace prevail where it seems domination. South Africa, need it be repeated, is one such country. The sooner this incontrovertible fact of political reality is accepted by us as well as by the West generally, the better will be all our chances to prevail against this monstrous ideology! * Lt Cdr H.G. Graser (B.A. Hons. Political Philosophy) is attached to the
Military Information Bureau, SADF.

\section{Verwysingsbronne}

Moorehead, A., The Russian Revolution, Bantam Books, NY, 1959. Barron, John, KGB. Corgi Books, Great Britain, 1979.

Deriabin, P. \& Gibney, F., KGB - The secret world, Ballantine Books, NY 1982.

Grieg, lan, The Communist challenge to Africa, Foreign Affairs Publishing Co., 1977. 